\title{
Impact of Selected Plant Species on Enzymatic Activity of Soil Substratum on Post-Mining Heaps
}

\author{
Agnieszka Błońska' ', Agnieszka Kompała-Bąba' ${ }^{1}$ Edyta Sierka', Lynn Besenyei² \\ Franco Magurno ${ }^{1}$, Kinga Frydecka', Wojciech Bierza ${ }^{1 *}$, Gabriela Woźniak ${ }^{1}$ \\ 1 Department of Botany and Nature Protection, Faculty of Biology and Environmental Protection, University of \\ Silesia in Katowice, Jagiellońska 28, 40-032 Katowice; Poland \\ 2 Faculty of Science and Engineering, University of Wolverhampton, Wulfruna Street, Wolverhampton WV1 \\ $1 \mathrm{LY}$, United Kingdom \\ * Corresponding author e-mail:wojciech.bierza@us.edu.pl
}

\begin{abstract}
The natural mineral resources (hard coal, sands, dolomites, lead and zinc ores) found in the Silesia and the excavation of them led to significant transformation or even degradation of the environment. The landscape of Upper Silesia was dominated by heaps created as a result of the accumulation of post-mining coal waste. These postindustrial sites are characterised by difficult conditions for the development of plant communities. Nevertheless, the heaps are spontaneously overgrowing and over time, a separate ecosystem can be observed (for heaps). The article analyzes the enzymatic activity of the substrate in relation to the selected dominant grass (Monocots) and herbaceous (Dicots) plant species. The aim of this study was to compare the activity of particular enzymes in soil substratum of the vegetation patches dominated by grass and herbaceous plants.
\end{abstract}

Keywords: carboniferous waste rock dumping grounds, mining heaps, enzymatic activities, herbaceous plants, grasses.

\section{INTRODUCTION}

The landscape of the Upper Silesia has been under strong impact of a man for many years. As a result of the exploitation of mineral deposits and the storage of waste coming from extraction and processing works, a lot of anthropogenic forms were created, such as spoil heaps or sedimentation pools. The spoil heaps are distinguished by specific harsh conditions (Bradshaw, 1993), such as: lack of water, high temperature, sometimes high salinity, low nutrient availability, small amount or lack of organic carbon (organic matter), small amount of nitrogen and macroelements $(\mathrm{P}, \mathrm{Mg}, \mathrm{K})$ [Bradshaw, 2000; Rostański, Woźniak 2007; Woźniak et al., 2003, Woźniak, 2010; Markowicz et al., 2015]. Since in many places the process of vegetation development is very slow, such heaps are susceptible to water or wind erosion [Bradshaw,
2000; Rostański, Woźniak 2007; Woźniak et al., 2003, Woźniak, 2010; Chmura et al., 2013, Molenda et al., 2013, Woźniak et al., 2015]. Moreover, some of them are undergoing - thermal and chemical activities [Bradshaw, 2000; Rostański, Woźniak 2007; Woźniak et al., 2003, Woźniak, 2010, Piekarska-Stachowiak et al., 2014].

Due to these unfavorable physical and chemical conditions, the biological activity of the subsoil is very low [Snajdr et al., 2013] and ecological processes proceed slowly [Nicia et al., 2014, Urbanova et al., 2011]. Some of the heaps were subjected to mainly technical and biological reclamation, but many of them were left without management. Over time, spoil heaps are colonized by plants and animals as a result of natural succession [Cohn et al. 2001, Chmura et al. 2011, Rahmonov et al. 2011, Błońska et al., 2013, Kompała-Baba and Bąa 2013, Chmura et al. 2013]. The majority of the spontaneously 
developed vegetation is dominated by grasses. Grasses are frequently considered as being better adopted to post-industrial sites harsh site conditions [Prach 2003, Woźniak et al. 2003, Rostański and Woźniak 2007, Frouz et al. 2008, Rahmonov 2009]

The soil enzymes produced by microorganisms and fungi seem to be one of the most important indicator of the substratum quality of the soil.

They are responsible for many processes that take place in the substratum, such as nitrogen fixation, release and availability of mineral substances to plants, catalysis of processes related to energy and organic matter decomposition [Russel and Wyczółkowski 2005]. The question arises what (if any) is the influence of some dominant species on the enzymatic activity of over 30 years of heaps depending on the dominant species (Calamagrostis epigejos, Poa compressa, Daucus carota, Tussilago farfara). The grasses are considered to be pioneer vegetation, preparing the soil through a rich root system and giving the opportunity to develop a new habitat [Rostański and Woźniak, 2007; Baryła, 2005]. It was assumed that the activity of particular enzymes may be higher in the vegetation patches dominated by grasses species than in the vegetation patches where herbaceous vegetation prevails. The aim of this study was to compare the activity of particular enzymes in the soil substratum of the vegetation patches dominated by grass and herbaceous plants.

\section{MATERIAL AND METHODS}

\section{Site description}

Coal deposits have been exploited in Europe since the 18th century. As the result of this activity, the environment was seriously transformed and many anthropogenic forms appeared which resulted in the appearance of visible effects in the environment, such as the coal-mine spoil heaps [Różkowski and Różkowski, 2011]. It is estimated that the post-mining waste has been deposited in around 380 heaps, which cover over 2,000 ha [Szczepańska and Twardowska, 1999]. Over 6000 $\mathrm{km}^{2}$ of the Upper Silesian Coal Basin (GZW) requires reclamation [Probierz et al., 2017]. This landscape forms are built with carboniferous sediments on the Pre-Cambrian crystalline massif [Cabała et al., 2004]. These objects are characterized by extreme abiotic conditions that change both in time and space and regulate the colonisation of heaps by plants [Woźniak 2010]. Most plants appeared on heaps using volatile predisposition of seeds (domination of anemochoric plants) and then were spread further. Three heaps „Sośnica” Heap (Gliwice) (50¹6’22”N, 18 44'43”E), „Wesoła” Heap (Mysłowice) $\left(50^{\circ} 10^{\prime} 28^{\prime \prime} \mathrm{N}, 19^{\circ} 5^{\prime} 44^{\prime \prime} \mathrm{)}\right)$ and „Kostuchna” Heap (Katowice) $\left(50^{\circ} 11^{\prime} 4{ }^{\prime \prime} \mathrm{N}, 19^{\circ} 0^{\prime} 33^{\prime} \mathrm{E}\right)$ were selected for further investigations. The location of the considered heaps is shown in Figure 1. According to Kondracki's classification, all of them are situated in the central part of the Silesian Upland macroregion, in the Katowice Upland mesoregions [Kondracki, 2002].

The study area is located in the transition climate zone between the temperate continental climate in the east and temperate oceanic climate in the west. The average annual temperature varies between 7 and $9^{\circ} \mathrm{C}$ and the precipitation between 700 and $900 \mathrm{~mm}$. The vegetation season lasts about 210-220 days [Kondracki, 2002].

The examined heaps are the landfills of carboniferous wastes, mainly made of claystone, siltstone, sandstone, conglomerate, coal shale and small quantities of coal [Rożkowski et al., 1993, Woźniak, 2010].

\section{Methods}

The vegetation samples were taken from heaps of the same age classes (over 30 years, according to the date of the end of material deposition), on which herbaceous vegetation appeared spontaneously [Woźniak, 2010].

In total, 75 research plots were established in the field in patches with the dominance of wood small-reed/bushgrass (Calamagrostis epigejos), flattened meadow-grass (Poa compressa), wild carrot (Daucus carota), coltsfoot (Tussilago farfara) and without vegetation (control).

For each of the plots, the list of species and species abundance (the coverage of individual species) were determined. Moreover, soil samples were taken from each plot at the depths between 0 and $10 \mathrm{~cm}$. In the laboratory, the soil samples were sieved through a $2 \mathrm{~mm}$ mesh sieve and cooled at $4^{\circ} \mathrm{C}$ degree until chemical analyses were carried out.

Acid and alkaline phosphatase were determined by means of spectrophotometric methods with $115 \mathrm{mM}$ of p-nitrophenylphosphate solution 


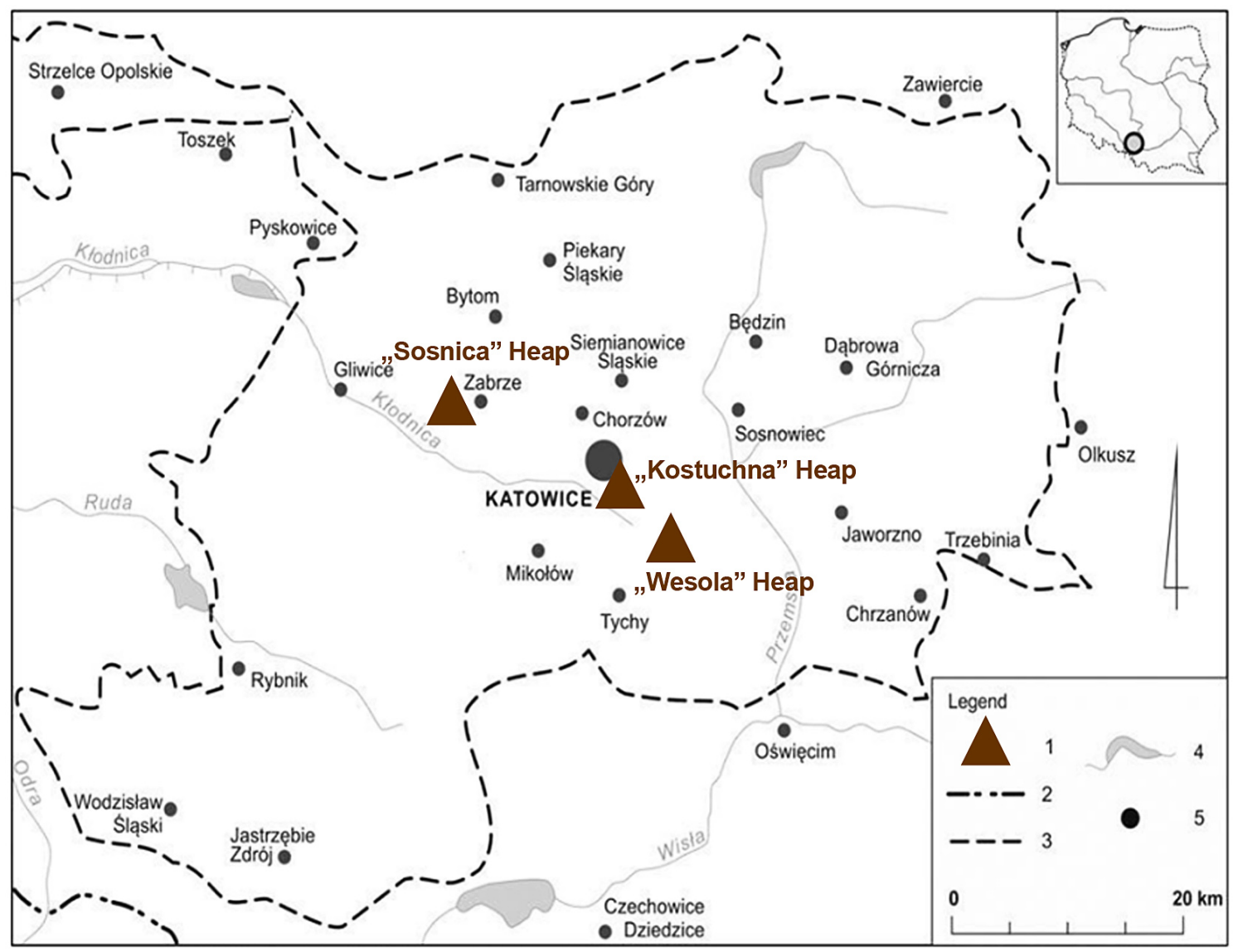

Figure 1. Location of investigated coal mine spoil heaps (marked in colour). Explanations: 1 - investigated heaps, 2 - State border, 3 - Area of Silesian Upland macroregion, 4 - water reservoirs, 5 - cities

as a substrate [Schinner et al., 1996]. Similarly, the urease activity was determined using urea as a substrate [Hoffmann, 1968]. The dehydrogenase activity was determined by using TTC, i.e. 2,3,5-triphenyltetrazolium chloride as a free radical acceptor [Schinner et al., 1996]. The activity of dehydrogenases was expressed in $\mu \mathrm{g}$ TPF $\mathrm{g}^{-1}$ d.m. $\mathrm{h}^{-1}$, urease in $\mu \mathrm{g} \mathrm{N}-\mathrm{NH}_{4} \mathrm{~g}^{-1}$ d.m. $\mathrm{h}^{-1}$ and acid phosphatase and alkaline phosphatase in $\mu \mathrm{g} \mathrm{NP}$ (nitrophenol) $\mathrm{g}^{-1} \mathrm{~d} . \mathrm{m}$. $\mathrm{h}^{-1}$. All enzymes were determined with a UV-VIS DR 5000 HACH-Lange spectrophotometer. The activity of dehydrogenases was measured at the wavelength of $\lambda=546 \mathrm{~nm}$, urease at $\lambda=580 \mathrm{~nm}$ and that of acid and alkaline phosphatase at $\lambda=410 \mathrm{~nm}$.

\section{Statystical analyses}

In order to obtain the normal distribution of data we used the Box-Cox transformation. The differences between investigated soil enzymes activity were tested using ANOVA with Welsh correction, and wherever significant differences were identified, a post hoc Tukey test was performed.

\section{RESULTS AND DISCUSSION}

The soils from the control and plots covered by the studied plant species differ significantly in terms of dehydrogenase $\left(\mathrm{F}_{\mathrm{w}}=7.358 ; p=0.000\right)$ (Figure. 2) as well as acid ( $\mathrm{F}_{\mathrm{w}}=21.770 ; p=$ $0.000)$ (Figure. 3) and alkaline $\left(\mathrm{F}_{\mathrm{w}}=35.831 ; p=\right.$ 0.000 ) (Figure. 4) phosphatase activity. Only in the case of urease $\left(\mathrm{F}_{\mathrm{w}}=3.293 ; p=0.150\right)$ (Figure. $5)$, no statistically significant differences in the activity of this enzyme were found in the studied soils. Higher activity for alkaline and acid phosphatases was recorded for the grasses, then herbs herbaceous vegetation plots. A similar situation was observed for the dehydrogenase activity.

Plots dominated by monocotyledonous species were characterized by a higher dominant coverage (C. epigejos $-48 \%$, P.compressa-33\%), in comparison with plots dominated by the dicotyledonous species (T. farfara-29\%, D. carota $-24 \%$ ) (Figure 6).

The well-developed root system has a positive effect on macroaggregates formation, soil organic matter (SOM) accumulation and soil stabilization 


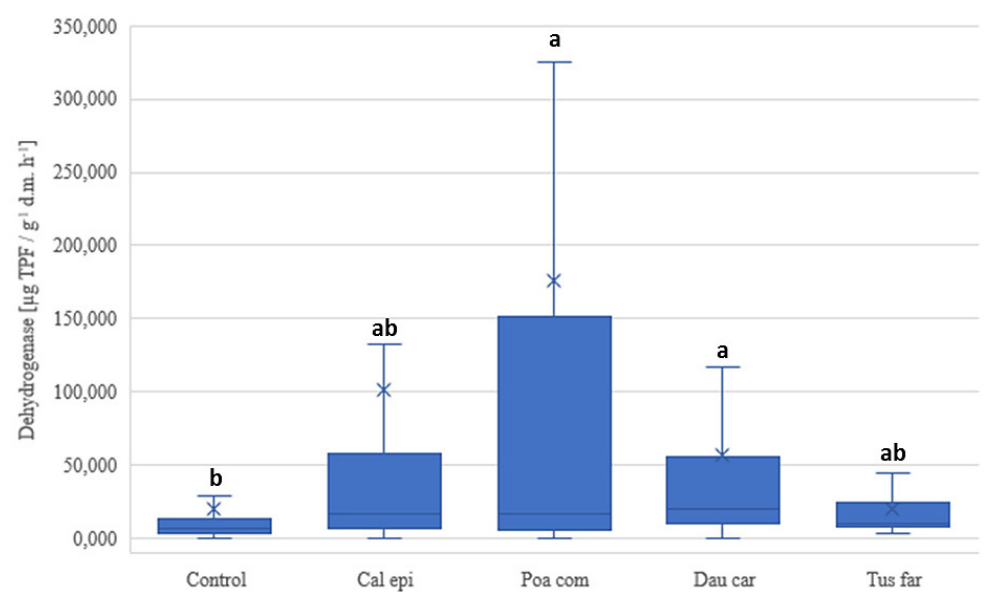

Figure 2. Comparison of the dehydrogenase activity in substrate samples from plots dominated by Calamagrostis epigejos (Cal epi), Poa compressa (Poa com), Daucus carota (Dau car) and Tussilago farfara (Tus far) and controls. Results marked with the same letter do not differ statistically significantly

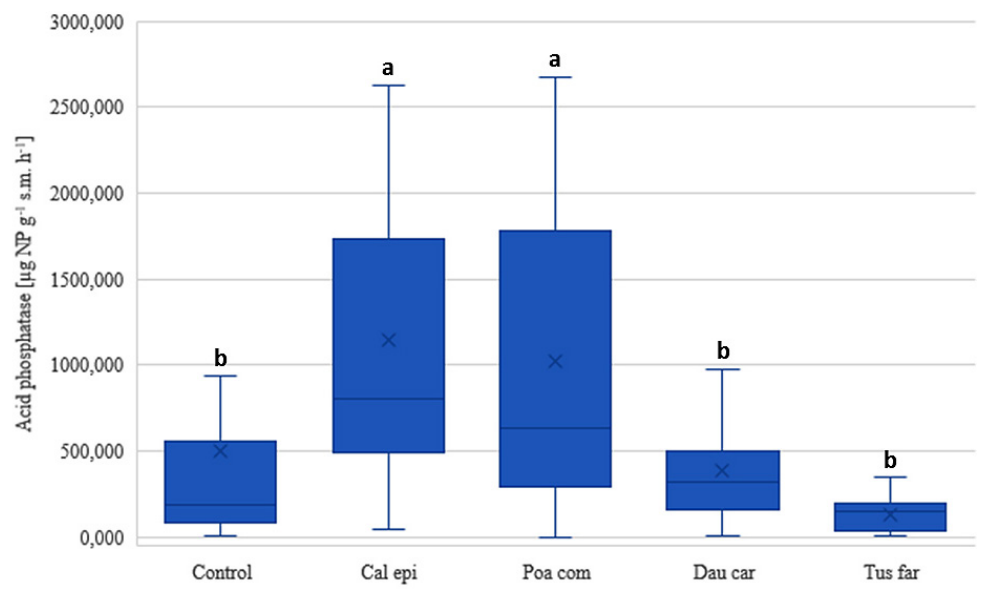

Figure 3. Comparison of the acid phosphatase activity in substrate samples from plots dominated by Calamagrostis epigejos (Cal epi), Poa compressa (Poa com), Daucus carota (Dau car) and Tussilago farfara (Tus far) and controls. Results marked with the same letter do not differ statistically significantly

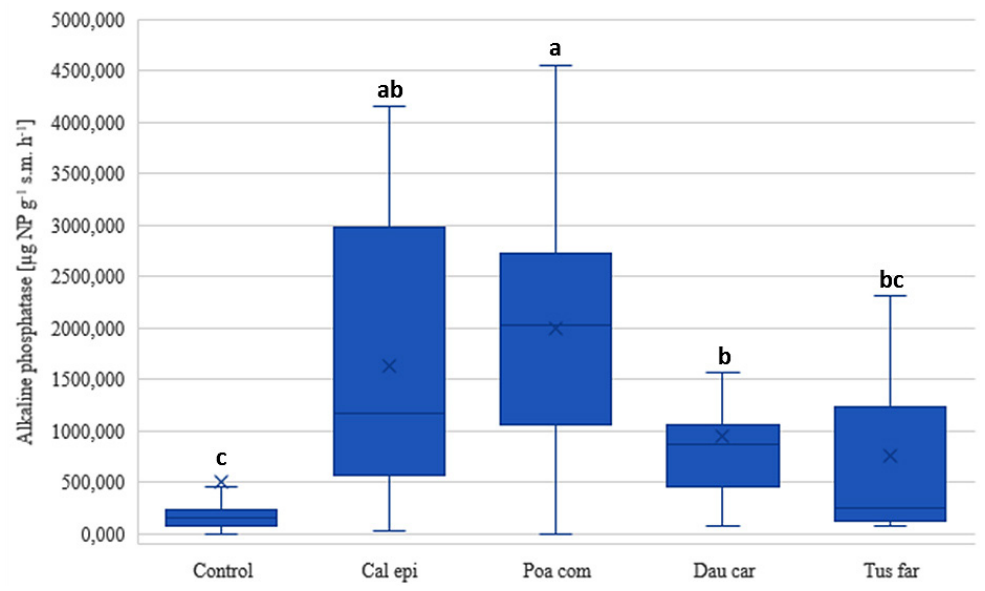

Figure 4. Comparison of the alkaline phosphatase activity in substrate samples from plots dominated by Calamagrostis epigejos (Cal epi), Poa compressa (Poa com), Daucus carota (Dau car) and Tussilago farfara (Tus far) and controls. Results marked with the same letter do not differ statistically significantly 


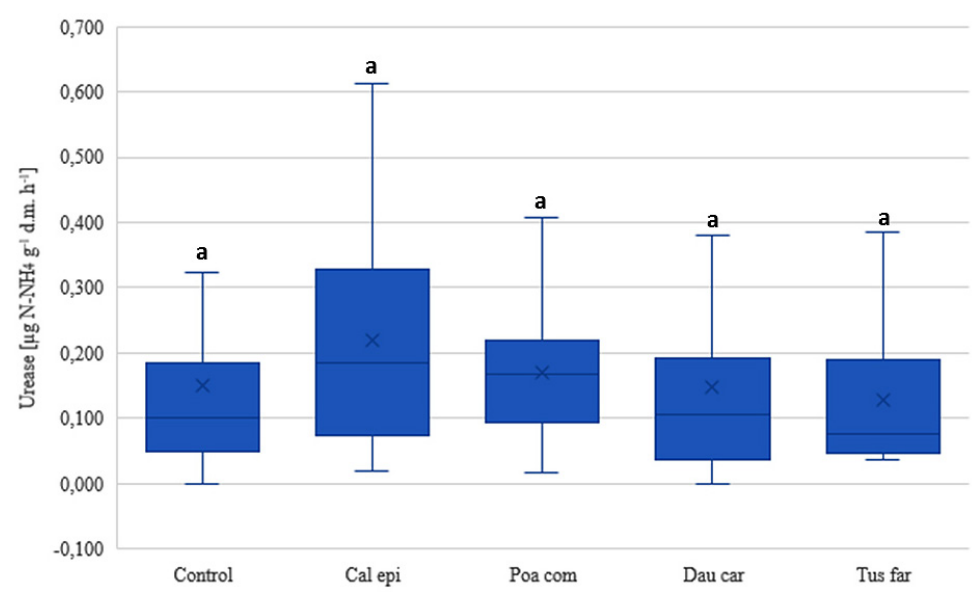

Figure 5. Comparison of the urease activity in substrate samples from plots dominated by Calamagrostis epigejos (Cal epi), Poa compressa (Poa com), Daucus carota (Dau car) and Tussilago farfara (Tus far) and controls. Results marked with the same letter do not differ statistically significantly

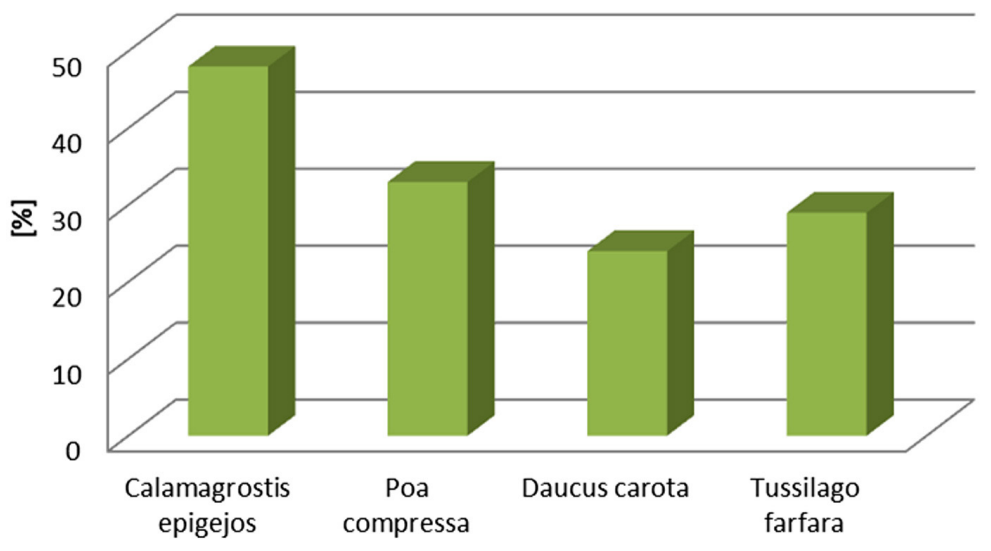

Figure 6. Comparison of the dominant species coverage

[Oades, 1984]. Moreover, the high abundance of plants can stimulate activity and biodiversity of microorganisms [Eisenhauer, 2013; Eisenhauer et al., 2017]. Therefore, the higher enzyme activity in grass dominated vegetation plots may be caused by high coverage and more developed grass root system, which generates the root exudates stimulating fungi and other microorganisms communities in the rhizosphere [Mommer et al., 2010; Mueller et al., 2013; Ravenek et al., 2014, Eisenhauer et al, 2017]. The studies conducted by Haynes [1999] have shown that the presence of grass increases the amount of SOM and improves the activities of the enzymes involved in $\mathrm{N}, \mathrm{P}$ and $\mathrm{S}$ cycling.

The dehydrogenase activity is an indicator of the redox system and a measure of respiratory activity of microorganisms [Kieliszewska-Rokicka, 2001; Bierza et al. 2012]. Dehydrogenase is active only within living organisms, and after a cell death, their degradation follows quickly. Therefore, the dehydrogenase activity indicates the presence of physiologically active microorganisms [Dick, 1997]. Higher dehydrogenase activity in soils from plots dominated by grassy species may be associated with a large amount of mycelium in the soil [Caravaca et al. 2004], because as mentioned above, the extensive root system of grasses stimulates the development of arbuscular fungi.

In soil ecosystems, phosphatases play a key role in the phosphorus cycle by catalysing the hydrolysis of organic phosphorus compounds to its inorganic forms, directly accessible to plants and soil organisms [Das and Varma, 2010]. The research conducted by Waldrop et al. [2000] and Ushio et al. [2010] indicate a positive correlation between the amount of mycelium in the soil and the activity of acid phosphatase. These authors suggest that fungi, compared to other microorganisms, can produce vastly more acid phosphatase. 


\section{CONCLUSIONS}

Higher enzymatic activity was observed in the sites with the dominance of grasses, compared to the sites with the plants of the Dicots families or the control sample. This may be due to the stimulating effect of the extensive root system of grasses, and thus a large amount of root exudates stimulating the development and activity of microorganisms. Lower enzyme activity on the plots of Daucus carota and Tussilago farfara may also be associated with lower abundance (biomass) of these species, in comparison to grasses.

On the basis of research and literature, it can be concluded that the enzymatic activity depends on the presence of vegetation and affects the formation of soil properties [Myśków, 1981, Kobus, 1995, Koper and Piotrowska, 1996, Myśków, 1996]. This is an example of a natural spontaneous revegetation, i.e. revival of a degraded postindustrial area.

\section{Acknowledgement}

This study was a part of InfoRevita project TANGO ID: 268600 financed by NCN. We wanted to thank the students participating in the project InfoRevita for their excellent technical support.

\section{REFERENCES}

1. Baryła R. 2005. The effect of irrigation with treated municipal sewage on the species composition of meadow mixtures. Łąkarstwo w Polsce, 8, 19-26 (in Polish).

2. Błońska A., Chmura D., Molenda T. 2013. The ecological conditions of the occurrence of drosera rotundifolia in man-made habitats. International Multidisciplinary Scientific GeoConference Surveying Geology and Mining Ecology Management, SGEM, 1, 947-954.

3. Bradshaw A.D. 1993. Restoration ecology as a science. Restoration Ecology, 1, 71-73.

4. Bradshaw A.D. 2000. The use of natural processes in reclamation-advantages and difficulties. Landscape and Urban Planning, 51, 89-100.

5. Cabała J., Teper E., Teper L., Małkowski E., Rostański A. 2004. Mineral composition in rhizosphere of plants grown in the vicinity of a $\mathrm{Zn}-\mathrm{Pb}$ ore flotation tailings pond. Acta Biologica Cracoviensia, Series Botanica, 46, 65-74.

6. Caravaca F., Alguacil M.M., Azcón R., Diaz G., Roldán A. 2004. Comparing the effectiveness of mycorrhizal inoculation and amendment with sugar beet, rock phosphate and Aspergillus niger to enhance field performance of the leguminous shrub Dorycnium pentaphyllum L. Applied Soil Ecology, 25(2), 169-180.

7. Chmura D., Błońska A., Molenda T. 2013. Hydrographic properties and vegetation differentiation in selected anthropogenic wetlands. International Multidisciplinary Scientific GeoConference Surveying Geology and Mining Ecology Management, SGEM, 1, 555-562.

8. Chmura D., Molenda T., Błońska A., Woźniak G. 2011. Sites of Leachate Inflows on Coalmine Heaps as Refuges of Rare Mountainous Species. Polish Journal of Environmental Studies, 20(3), 551-557.

9. Cohn V. J., Rostański A., Tokarska-Guzik B., Trueman I.C., Woźniak G. 2001. The flora and vegetation of and old Solvay process tip in Jaworzno (Upper Silesia, Poland). Acta Societatis Botanicorum Poloniae, 70, 47-60.

10. Das S.K., Varma A. 2010. Role of enzymes in maintaining soil health. In: Shukla, G., Varma, A. [Eds.]. Soil enzymology. Springer Berlin Heidelberg. pp. 25-42.

11. Dick R.P. 1997. Soil enzyme activities as integrative indicators of soil health. In: Pankhurst C., Doube B.M., Gupta V.V.S.R. [Eds.]. Biological indicators of soil health. CAB International. pp. 121-156.

12. Eisenhauer N., Dobies T., Cesarz S., Hobbie S.E., Meyer R.J., Worm K., Reich P.B., 2013. Plant diversity effects on soil food webs are stronger than those of elevated $\mathrm{CO}_{2}$ and $\mathrm{N}$ deposition in a longterm grassland experiment. Proceedings of the $\mathrm{Na}$ tional Academy of Sciences, 110(17), 6889-6894.

13. Eisenhauer N., Lanoue A., Strecker T., Scheu S., Steinauer K., Thakur M.P., Mommer L., 2017. Root biomass and exudates link plant diveristy with soil bacterial and fungal biomass. Scientific Reports, 7, 44641.

14. Frouz J., Prach K., Pižla V., Háněla L., Starýa J., Tajovskýa K., Maternad J., Balíka J., Kalč́́ka J., Řehounkováb K. 2008. Interactions between soil development, vegetation and soil fauna during spontaneous succession in post mining sites. European Journal of Soil Biology, 44, 109-121.

15. Haynes R.J. 1999. Size and activity of the soil microbial biomass under grass and arable management. Biology and Fertility of Soils, 30(3), 210-216.

16. Hoffmann E. 1968. Phosphatases in the enzyme system of cultivated soils (in Germany) and possibilities of determining their activity. Zeitschrift für Pflanzenernährung und Bodenkunde, 118, 153-160.

17. Kompała-Bąba A., Bąba W. 2013. The spontaneous succession in a sand-pit - the role of life history traits and species habitat preferences. Polish Journal of Ecology, 61, 13-22. 
18. Kondracki J. 2002. Regional geography of Poland. PWN, Warsaw (in Polish).

19. Koper J., Piotrowska A. 1996. Enzymatic activity of podzolic soil depending on the cultivation of plants in crop rotation and monoculture. Roczniki Gleboznawcze, 3, 89-100 (in Polish).

20. Koperski T., Cukiernik Z., Wiśniewski J. 2008. Aspects and conditions related to the transformation of mining waste into products [In] Waste management - current status and planned changes. Nowe zasady gospodarowania odpadami wydobywczymi. Materiały Warsztatów, Katowice (in Polish).

21. Markowicz A., Woźniak G., Borymski S., Piotrowska-Seget Z., Chmura D. 2015. Links in the functional diversity between soil microorganisms and plant communities during natural succession in coal mine spoil heaps. Ecological Research, 30(6), 1005-1014.

22. Molenda T., Błonska A., Chmura D. 2013. Hydrochemical diversity of antropogenic wetlands developed in disused sandpits. International Multidisciplinary Scientific GeoConference Surveying Geology and Mining Ecology Management, SGEM 1, 547-553.

23. Myśków W. 1981. Attempts to use microbial activity indicators to assess soil fertility. Postępy Mikrobiologii, 20 (3/4), 173-192 (in Polish).

24. Myśków W., Stachyra A., Zięba S., Masiak D. 1996. Soil biological activity as an indicator of its fertility. Roczniki Gleboznawcze, 47, 89-99 (in Polish).

25. Nicia P., Bejger R., Błońska A., Zadrozny P., Gawlik A. 2014. Characteristics of the habitat conditions of ash-alder carr (Fraxinio-Alnetum) in the Błedowskie Swamp. Journal of Food, Agriculture and Environment, 12(2), 1227-1232.

26. Oades J.M. 1984. Soil organic matter and structural stability: mechanisms and implications for management. Plant and Soil, 76(1-3), 319-337.

27. Piekarska-Stachowiak A., Szary M., Ziemer B., Besenyei L., Woźniak G. 2014. An application of the plant functional group concept to restoration practice on coal mine spoil heaps. Ecological Research, 29(5), 843-853.

28. Prach K. 2003. Spontaneous succession in CentralEuropean man-made habitats: what information can be used in restoration practice? Applied Vegetation Science, 6, 125-129.

29. Probierz K., Gawor Ł., Jonczy I., Marcisz M. 2017. Valorisation of post-mining waste dumping grounds from the mines of Katowicki Holding Węglowy S.A. Gospodarka surowcami mineralnymi - Mineral Resources Management, 33(1), 35-50 (in Polish).

30. Rahmonov O. 2009. The chemical composition of plant litter of black locust (Robinia pseudoacacia L.) and its ecological role in sandy ecosystems. Acta Ecologica Sinica, 29, 237-243.

31. Rahmonov O., Rahmanova M., Snytko V.A., Szc- zypel T. 2011. Anthropogenic disturbance to vegetation on the poligon-transect in the Kulikalon depression (Tajikistan) Geography and Natural Resources, 32, 386-393.

32. Rostański A., Woźniak G. 2007. Grasses (Poaceae) on post-industrial waste sites in course of spontaneous succession. Fragmenta Floristica et Geobotanica, 9, 31-42.

33. Różkowski A., Różkowski K., 2011. The impact of coal mining activities on the formation of the water environment of the Upper Silesian Coal Basin in the long-term. Biuletyn Państwowego Instytutu Geologicznego, 445, 583-592 (in Polish).

34. Russel R.S., Wyczółkowski A.J. 2005. Methods for determining enzyme activity in soil. Acta Agrophysica Rozprawy i Monografie. 3 (in Polish).

35. Schinner F., Öhlinger R., Kandeler E., Margesin R. 1996. Methods in soil biology, Springer-Verlag, Berlin, Heidelberg, New York, pp. 241-243.

36. Šnajdr J., Dobiášová P., Urbanová M., Petránková M., Cajthaml T., Frouz J., Baldrian P. 2013. Dominant trees affect microbial community composition and activity in post-mining afforested soils. Soil Biology and Biochemistry, 56, 105-115.

37. Szczepańska J., Twardowska I. 1999. Distribution and environmental impast of coal-mining wastes in Upper Silesia. Poland Environment and Geology, 38(3), 249-258.

38. Urbanova M., Kopecky J., Valaskova V., Saganova-Mareckova M., Elhottova D., Kyselkova M., Moenne-Loccoz Y., Baldrian P. 2011. Development of bacterial community during spontaneous succession on spoil heaps after brown coal mining. FEMS Microbiology Ecology, 78, 59-69.

39. Ushio M., Kitayama K., Balser T.C. 2010. Tree species effects on soil enzyme activities through effects on soil physicochemical and microbial properties in a tropical montane forest on Mt. Kinabalu, Borneo. Pedobiologia, 53(4), 227-233.

40. Waldrop M.P., Balser T.C., Firestone M.K. 2000. Linking microbial community composition to function in a tropical soil. Soil Biology and Biochemistry, 32(13), 1837-1846.

41. Woźniak G., Pasierbiński A., Rostański A. 2003. The diversity of spontaneous woodland vegetation on coals mine heaps of Upper-Silesian industrial region. Archives of Environmental Protection, 29, 93-105.

42. Woźniak G. 2010. Diversity of vegetation on coalmine heaps of the Upper Silesia (Poland). In: Margesin R, Schinner F (Eds) Manual of soil analysis-monitoring and assessing soil bioremediation. Szafer Institute of Botany. Polish Academy of Science, Kraków, p 310.

43. Woźniak G., Markowicz A., Borymski S., Piotrowska-Seget Z., Chmura D., Besenyei L. 2015. The relationship between successional vascular plant assemblages and associated microbial communities on coal mine spoil heaps. Community Ecology, 16(1), 23-32. 